\title{
DIE VERBAND TUSSEN WERKNEMERTEVREDENHEID EN ORGANISASIEVERBONDENHEID
}

\author{
A A S PRETORIUS \\ G ROODT \\ Departement Menslikehulpbronbestuur \\ Randse Afrikaanse Universiteit
}

\begin{abstract}
The relationship between employee satisfaction and organisational commitment. The primary goal of the study is to determine whether a relationship exists between employee satisfaction and organisational commitment. A secondary goal is to determine whether any biographical variables mediate this relationship. Standardised instruments were used for operationalising these two contructs. A sample of convenience yielded 167 respondents out of a sampling frame of 300 employees from a financial organisation. Only 145 respondents returned fully completed questionnaires that were used for final analysis. Responses from both questionnaires were subjected to a factor and item analysis. A statistically significant relation between employee satisfaction and organisational commitment was found. The implications of the findings are discussed further.
\end{abstract}

\section{OPSOMMING}

Die primêre doel van die studie is om vas te stel of daar 'n verband bestaan tussen werknemertevredenheid en organisasieverbondenheid. 'n Sekondêre oogmerk is om te bepaal of enige biografiese veranderlikes hierdie verband medieer. Gestandaardiseerde instrumente is gebruik om hierdie twee konstrukte te operasionaliseer. 'n Gerieflikheidsteekproef het 167 respondente uit 'n steekproefraamwerk van 300 werknemers van 'n finansiële instelling opgelewer. Slegs 145 respondente het volledig-voltooide vraelyste terugbesorg, wat vir finale ontleding gebruik is. Response op albei vraelyste is aan 'n faktor- en itemontleding onderwerp. 'n Statisties-beduidende verband tussen werknemertevredenheid en organisasieverbondenheid is gevind. Die implikasies van die bevindinge word verder bespreek.

\section{SYNOPSIS}

Technological advancement, a recognized force of change, has a direct impact on the existence of individuals within specialist/support functions. Leaders and Managers are being enabled to become independent and are, as a result of that, faced with the challenge to improve employees' levels of commitment in order to gain and maintain global competitive advantage.

Employee satisfaction is defined by several authors. According to them, it reflects the individual's perception and evaluation of his/her work, which are influenced by unique personal circumstances like needs, values and expectations. Due to the fact that employee satisfaction embraces employees' emotional feelings, it could have a major impact on their lives as well as monetary implications to the organisation.

The organisational commitment literature includes a large number of explanatory and descriptive concepts without any serious attempt for integration and parsimony (Roodt, 1991). There also appears to be a definite lack of conceptual clarity within the organisational commitment literature (Morrow, 1983). Kanungo (1982) suggested an integrated, cognitive approach (known as the motivational approach) that creates order and conceptual clarity. Organisational commitment is defined by Roodt (1997) as a cognitive predisposition that the organisation has the ability to satisfy salient needs in the work context. In the view of this, a uniform definition was developed by Roodt (1997) to operationalise commitment in these different work-related contexts, including that of union commitment. Hereby, most of the major points of criticism against existing definitions and questionnaires were addressed. In other studies respondents made no distinction between these different foci and Roodt (1997) concluded that this distinction may only be of theoretical value.

No evidence could be found in the literature that suggests an empirical link between employee satisfaction and organisational commitment, although it is suggested by theory. The research question of this study therefore is: "Is there a relationship between employee satisfaction and organisational commitment?

Requests for copies should be addressed to: G Roodt, Department of Human Resource Management, RAU University, PO Box 524, Auckland Park, 2006
This study was conducted in the People Management division of a financial organisation in South Africa, which employs about 30 000 people. The sampling frame consisted of 300 employees in the Patterson B,C and D bands. Of the 167 questionnaires that were returned (55\%) only 145 were fully completed and included for final analysis.

The shortened Minnesota Satisfaction Questionnaire (MSQ 20) developed by Weiss, Dawes, England and Lofquist (1967) was used to measure employee satisfaction. The questionnaire consisted of 20 items and yielded an acceptable internal consistency of 0,90 (Kaplan, 1990).

The organisational commitment questionnaire developed by Roodt (1997) was used to operationalise organisational commitment as a motivational approach and as a cognitive predisposition as conceptualised by Kanungo (1982). The questionnaire consisted of 38 items, each with a five-point intensity response scale anchored at the extreme poles. The questionnaire yielded an acceptable Cronbach Alpha of 0,914 (Roodt, 1997).

The questionnaires were in English and were distributed through the company's intranet and respondents could respond either via e-mail, normal office mail or could submit completed questionnaires personally. Respondents were ensured about the confidentiality of their responses. The questionnaires were distributed within the organisation only. The instrument was copy and write protected and could therefore not be copied.

Responses on both questionnaires were analysed the same way. Responses were first factor analysed (first and second level analyses were conducted) and iterative item analysis were executed on the obtained scales. The Employee Satisfacton Questionnaire (Weiss et al., 1967) yielded a single scale with a Cronbach Alpha of 0,91. The Organisational Commitment Questionnaire (Roodt, 1997) yielded two scales where the fist scale represented the organisational involvement construct and the second scale was related to career involvement. The Alpha coefficients were respectively 0,95 and 0,85.

Results indicate statistically, significant relationships between employee satisfaction and organisational commitment as well as career commitment scores for the total sample. 
The findings suggest a satisfied, homogeneous group of employees within the People Management division, with no biographic variables mediating the relationships between employee satisfaction and organisational or career commitment scores.

Ten einde ' $n$ kompeterende markaandeel te bekom en te behou, is dit van kardinale belang dat organisasies voortdurend by veranderende omstandighede moet kan aanpas. Om hierdie rede word die wêreld van werk, ook binne mensbestuur, gekenmerk deur grootskaalse veranderinge (waaronder herstrukturering), veral op tegnologiese gebied. In die onderhawige studie word daar gefokus op die mensbestuurdivisie van 'n finansiële instelling wat deur tegnologiese veranderinge geraak is. Daar is verwag dat hierdie veranderinge werknemers se werktevredenheid en ook hulle organisasieverbondenheid wesentlik sou raak.

Dit is belangrik om diverse werknemers saam te snoer in ' $n$ verbonde werksmag, gerig op 'n organisatoriese visie ten einde die voortdurende aanpassings waarna hierbo verwys word, te bewerkstellig (Storm \& Roodt, 2002). Bogenoemde omstandighede het tot gevolg dat organisasies opnuut fokus op hul menslikehulpbronne as hul belangrikste bate en is gevolglik op soek na maniere om werknemers se verbondenheidsvlakke te verhoog (Hoole, 1997).

Organisasies verteenwoordig huidig, as gevolg van hulle dinamiese aard, die mees komplekse sosiale strukture. Werknemers is een van die rolspelers in die organisasie en dit is juis hulle betrokkenheid en toewyding wat die organisasie tot voortdurende kompetisie aanmoedig. Die verhouding tussen die organisasie en mense is egter interafhanklik van aard en beide partye mag op die ander se vermoë om positiewe resultate te behaal, impakteer (Sempane, Rieger \& Roodt, 2002).

\section{Werknemertevredenheid}

Werknemertevredenheid is heel waarskynlik een van die mees omvangryke nagevorsde onderwerpe in die industriële- bedryfen organisasiesielkunde veld (Coster, 1992). 'n Magdom navorsingartikels oor werknemertevredenheid het reeds die lig gesien. In sy 1976 oorsig het Locke genoem dat sy skatting van 3350 artikels op werknemertevredenheid as konserwatief beskou kan word (Locke, 1976). Ten spyte van hierdie omvangryke studies is daar egter steeds heelwat verhoudinge wat werknemertevredenheid voorafgaan maar ook wat daaruit voortspruit wat nog oop vir debatering is (Cranny, Smith \& Stone, 1992).

Werksbevrediging (die bevrediging van werkspesifieke behoeftes) en werknemertevredenheid ('n toestand/ houding van tevredenheid met die werk) is twee afsonderlike konsepte wat onlosmaaklik aan mekaar verbonde is. Die aanname kan gemaak word dat hoe groter werksbevrediging, hoe groter werknemertevredenheid. Hierdie aanname sal verder hieronder toegelig word.

Vir die doel van hierdie studie word die volgende definisies van werkbevrediging en werknemertevredenheid voorgestel:

Werksbevrediging het te doen met die bevrediging van markante behoeftes in die werkkonteks en kan varieer tussen geen en volkome bevrediging. Die bevrediging van werkbehoeftes gee weer aanleiding tot werknemertevredenheid.

Werknemertevredenheid is ' $n$ positiewe of negatiewe gesindheid (houding/emosie) wat by 'n werknemer voorkom, gebaseer op sy/haar evaluasie van die inhoud/konteks van sy/haar werk op 'n gegewe tyd (Visser \& Breed, 1997).

Aangesien werknemertevredenheid werknemers se geneentheid of emosionele gevoelens behels, het dit 'n reuse impak op hul lewens (Sempane et al., 2002). Die mees algemene nagevolge van werknemertevredenheid op werknemers kan beskryf word as die effek op liggaamlike gesondheid en hoë ouderdom; geestelike gesondheid en 'n impak op die werknemer se sosiale lewe in die algemeen. Interaksie tussen die werknemer se gevoelens oor sy werk en sy sosiale lewe kom voor (Locke, 1976). Coster (1992) het ook die feit dat werk 'n belangrike effek op die algehele kwaliteit van die werknemer se lewe kan hê, ondersteun.

Werknemertevredenheid geskied nie in isolasie nie, aangesien dit afhanklik is van organisatoriese veranderlikes soos struktuur, grootte, vergoeding, werksomstandighede en leierskap, wat organisatoriese klimaat bepaal. Organisatoriese klimaat en -kultuur (alhoewel baie moeilik om te verander) kan bevorder word deur die behaling van werknemertevredenheid en organisatoriese doelwitte (Sempane et al., 2002).

Die literatuur en navorsing het tot vandag toe in 'n groot mate die individu en sy unieke persepsies/gesindhede geiignoreer Individue mag ooreenstemmende gesindhede met betrekking tot hulle werk hê, maar hul evaluering van die inhoud sowel as die belangrikheid daarvan, mag beduidend verskil. Hierdie leemte in die konseptualisering van die konstruk het gelei tot die eksklusiewe gebruik van kwantitatiewe metingsprosedures ten einde die vlak van werknemertevredenheid te bepaal (Visser \& Breed, 1997).

Die moelikheidsgraad wat oor die algemeen ondervind word om die konstruk werknemertevredenheid te definieer, beperk teoretiese en empiriese vergelyking (Visser \& Breed, 1997). Daar word voorgestel dat konflikterende resultate wat in verskeie studies van werknemertevredenheid verkry word, toegeskryf kan word aan die feit dat verskillende navorsers die term verskillend definieer. Verskillende uitdrukkings word ook in afwisseling gebruik met ander uitdrukkings soos "moraal, werksatisfaksie, gesindhede en opinies".

Drie hoofdenkskole van oorsake is vanvir werknemertevredenheid word genoem, naamlik: liggaamlik-ekonomies (toepaslike werkstoestande), sosiaal (die belangrikheid van effektiewe toesig en samewerking tussen en met groepe) en die aard van werk (werknemers word toegelaat om verstandelik uitdagende take te verrig) (Locke, 1976).

Werksverwante veranderlikes (byvoorbeeld werkslas, eienskappe van die pos, en taakverwante verantwoordelikhede) word as belangrik geag ten einde verhoudings met betrekking tot werk te verstaan, soos byvoorbeeld werknemertevredenheid, aangesien hierdie veranderlikes 'n onmiddellike en sterk situasionele invloed skep (Davis-Blake \& Pfeffer, 1989; Zeitz, 1990). Empiriese navorsing (byvoorbeeld Agho, Mueller, \& Price, 1993; Carlopio \& Gardner, 1995) wys daarop dat hierdie werksverwante veranderlikes 'n direkte impak op werktevredenheid het.

Werknemertevredenheid, in watter vorm dit ookal mag voorkom, kan ook verder in verband gebring word met afhanklike veranderlikes soos omset, afwesigheid, produktiwiteit, algemene higiëne faktore, arbeidsonrus en prestasiebeoordeling (Visser \& Breed, 1997). Hierdie afhanklike veranderlikes het monetêre implikasies vir organisasies en juis daarom word so 'n groot klem op die navorsing hiervan in die Bedryfsielkunde en Menslikehulpbronbestuur geplaas. Die politieke veranderinge en herhaaldelike arbeidsonrus noodsaak 'n groter bewuswording van werknemers en hulle vlak van werknemertevredenheid. Arbeidswetgewing was het nog nooit voorheen so ten gunste van die reg van die werknemer beskerm soos juis nou nie.

Wanneer verwys word na algehele werknemertevredenheid of spesifieke aspekte of fasette daarvan, is dit nodig dat sekere algemene elemente erken moet word wanneer hierdie terme gedefinieer word: 
- werknemertevredenheid is 'n gesindheid, of meer eenvoudig gestel, 'n "gevoel" gebaseer op 'n evaluering van werkstoestande in geheel.

- Hierdie reaksies en persepsies is van 'n individuele aard Hierdie gesindhede kan van tyd tot tyd wissel, soos wat situasies verander (Gurin, Veroff \& Feld, 1960; Stoner \& Freeman, 1992; Vroom, 1964).

\section{Organisasieverbondenheid}

Organisasieverbondenheid reflekteer die mate waarin die individu homself met ' $n$ organisasie identifiseer en tot sy doelwitte verbind. Bestuur word aangeraai om werknemertevredenheid te verhoog ten einde hoër vlakke van verbondenheid te bereik. In ruil hiervoor, kan hoër verbondenheid hoër produktiwiteit te-weeg bring (Kreitner \& Kinicki, 1998).

'n Definitiewe leemte aan konseptuele helderheid kom in organisasie-verbondenheidsliteratuur voor (Morrow, 1983). Organisasieverbondenheid as studieveld word dus gekarakteriseer deur konsepte en definisies wat nie op 'n evolusionêre wyse ontwikkel het in terme van betekenis en verhoudings met verwante verbondenheidskonsepte nie. Vorige navorsers was geneig om eerder hul eie verbondenheidsdefinisies te formuleer in plaas van uitbreiding op bestaande benaderings (Morrow, 1983). Die organisasie-verbondenheidsliteratuur huisves 'n groot hoeveelheid verklarende en beskrywende konstrukte, sonder enige poging tot spaarsamigheid en integrasie (Roodt, 1991).

Kanungo (1982) skep orde in die bogenoemde tekortkoming aan konseptuele duidelikheid deur ' $n$ konseptuele benadering voor te stel wat gebruik kan word om die fenomeen van vervreemding en betrokkenheid in enige spesifieke aspek van die mens se lewe te bestudeer. Hierdie benadering is as ' $n$ motiveringsbenadering gekarakteriseer wat die toestand van vervreemding en betrokkenheid met die kognitiewe oortuigings van die werknemers verbind.

In die motiveringsbenadering (Kanungo, 1982) word die konsepte van betrokkenheid en vervreemheid as keersye van dieselfde muntstuk beskou. Sosioloë gebruik konstant die term 'vervreemding' in hul studies van werksgedrag, terwyl sielkundiges die term 'betrokkenheid' gebruik. Kanungo (1982) het 'n poging aangewend om die konsepte van vervreemding (wat kan lei tot gebrek aan werknemertevredenheid) en betrokkenheid (mate van organisasieverbondenheid) te verduidelik en te operasionaliseer deur verskeie huidige sosiologiese en sielkundige benaderinge tot hierdie konsepte krities te ondersoek.

Die motiveringsbenadering tot die studie van vervreemding en betrokkenheid, soos voorgestel deur Kanungo (1982), stel 'n geïntegreerde raamwerk vir toekomstige sielkundige en sosiologiese navorsing voor. Kanungo (1982) se nuwe raamwerk asook die nuwe metingstegnieke wat in sy boek voorgestel word, dui dus nuwe rigting vir toekomstige navorsing aan. Dit behoort tot 'n meer sistematiese begrip van die verskynsel van die graad van werkbetrokkenheid oor verskeie kulture heen te lei.

Die graad van werkbetrokkenheid word as 'n kontinuum beskou waarop vervreemding en beheptheid as uiterste pole voorkom. Werkbetrokkenheid word as die kognitiewe predisposisie dat die werk oor die potensiaal beskik om markante behoeftes te bevredig, gedefinieer (Roodt, 1991).

Werkvervreemding word as die kognitiewe predisposisie dat werk nie oor die potensiaal beskik om markante behoeftes te bevredig nie, gedefinieer. Vervreemding word deur sekere vorme van onttrekking, byvoorbeeld arbeidsomset, afwesigheid en laatkom gekenmerk (Beehr \& Gupta, 1978).
Werkbeheptheid word deur Roodt (1991) as die kognitiewe predisposisie dat die werk die potensiaal besit om markante behoeftes in die werksituasie te bevredig, gedefinieer; waar markante behoeftes in hierdie opsig verband hou met die vermyding van irrasionele vrese en perfeksionistiese neigings. Daar word geteoretiseer dat persone met hoë werkbetrokkenheidstellings werkbehep sal wees. Stewart (1986) het drie hoofredes wat tot werkbeheptheid kan lei geïdentifiseer naamlik: 'n Persoon se gevoel van eiewaarde word primêr aan sy werk gekoppel; 'n beduidende vrees vir mislukking is teenwoordig of 'n persoon het sterk perfeksionistiese neigings. Naughton (1987) was van mening dat werkbehepte persone geleenthede om in ander niewerkverwante aktiwiteite betrokke te raak, sal uitsluit of beperk. Dieselfde teoretiese uitgangspunt word in ander foci (soos organisasies) voorgestel.

Hierdie nuwe motiveringsbenadering het twee hoofvoordele bokant die vorige sosiologiese en sielkundige benaderings naamlik: die benadering integreer die twee paralelle strome van sosiologiese en sielkundige denke oor werksvervreemding en werksbetrokkenheid. Tweedens, voorsien dit 'n breër raamwerk vir kruis-kulturele navorsing. Fokus behoort nie slegs op intrinsieke motivering, maar ook op ekstrinsieke motivering geplaas te word. Duidelike onderskeid tussen betrokkenheid in 'n spesifieke werk en betrokkenheid by werk oor die algemeen behoort getref te word. Die verband tussen die sielkundige welstand van werknemers en hulle werksbetrokkenheid behoort ook verder ondersoek te word.

In teenstelling met die voorgaande teoretisering word 'n meerdimensionele benadering tot organisasieverbondenheid deur Mowday, Steers en Porter (1979) voorgestaan. Hulle het organisasieverbondenheid gedefinieer as die werknemer se begeerte om lid te bly van die organisasie, sy/haar gewilligheid om inspanning uit te oefen (sy of haar uiterste beste te gee) vir die organisasie en die aanvaarding en vertroue in die organisasiewaardes en doelwitte. Hierdie benadering bied benewens die gebrek aan konseptuele helderheid ook uitdagings in terme van statistiese verwerkingstegnieke.

\section{Die verband tussen werknemertevredenheid en organisasieverbondenheid}

Hierdie area het betekenisvolle bestuursimplikasies aangesien duisende studies reeds die verhouding tussen werknemertevredenheid en ander organisatoriese veranderlikes ondersoek het (Kreitner \& Kinicki,1998).

In die dekade voor 2000 het die gewildheid van organisasieverbondenheid as konsep in die organisasiegedragliteratuur toegeneem. 'n Aansienlike getal empiriese studies is gedoen op die oorsake en die gevolge van organisasieverbondenheid sowel as om die verband met ander werkverwante veranderlikes te bepaal. Organisasieverbondenheid as 'n oorsaak is gebruik om werknemers se afwesigheid, prestasie, omset en ander gedrag te voorspel. Organisasie-verbondenheid as 'n gevolg, is weer gekoppel aan verskeie persoonlike veranderlikes, roluiteensettinge en aspekte van die werksomgewing wat wissel van werkseienskappe tot dimensies van organisasiestruktuur. In toevoeging hiertoe het verskeie ander veranderlikes (byvoorbeeld werksbetrokkenheid en werktevredenheid) verhoudings met organisasieverbondenheid getoon (Mathieu \& Zajac, 1990).

Organisasieverbondenheid is gedefineer en gemeet op verskillende maniere. Die verskillende definisies en metings deel egter 'n gemeenskaplike tema, naamlik dat organisasie-verbondenheid gesien word as 'n band of koppeling van die individu tot die organisasie (Mathieu \& Zajac, 1990). 
Indien, daar werknemertevredenheid voorkom, bring dit 'n spesifieke emosie tot stand wat gebaseer is op kognisie en behoort daar gevolglik ' $n$ teoretiese verband te wees tussen werknemertevredenheid en organisasieverbondenheid (Bergh \& Theron, 2003).

Die aanname kan dus gemaak word dat hoe minder tevrede die werknemer is met dit wat die organisasie hom/haar kan bied, hoe groter sal sy/haar gevoel van vervreemding van die organisasie wees. Die werknemer se houding teenoor werkfasette kan vinnig geformuleer word en toon ' $n$ groter variansie as verbondenheid wat weer meer stabiel en langdurig is. Sterk interaktiewe effekte tussen tevredenheid en verbondenheid kom dus voor (Naumann, 1993).

Die meerderheid vorige studies het grotendeels op algehele werknemertevredenheid en die verband met organisasieverbondenheid, werksprestasie en ander werksverwante resultate gekonsentreer. Die meeste van die navorsking in hierdie area is in die Weste ('n ontwikkelde land-konteks) uitgevoer (Yousef, 1998).

Ondersoeke wat wel gedoen is ten opsigte van die oorsaaklike verhouding tussen organisasieverbondenheid en wernemertevredenheid, het teenstrydige bevindinge opgelewer.

Kanungo (1982) het na 'n reeks studies verwys wat die verhouding tussen werknemertevredenheid en werksbetrokkenheid ondersoek het. Alhoewel hierdie studies 'n positiewe verhouding tussen intrinsieke behoeftebevrediging en werkbetrokkenheid bevestig, bestaan daar noemenswaardige dubbelsinnigheid in die verhouding tussen ekstrinsieke behoeftebevrediging en werkbetrokkenheid.

Die verhouding tussen organisasieverbondenheid en werknemertevredenheid word as beide kontroversieel en teenstrydig beskou. Die meerderheid teoretiese en empiriese bewyse dui daarop dat werknemertevredenheid organisasieverbondenheid voorafgaan (Testa, 2001).

\section{Die doel van hierdie studie}

In die lig van voorgaande bespreking, is die primêre doel van die studie om vas te stel of daar 'n verband bestaan tussen werknemertevredenheid en organisasieverbondenheid binne die mensbestuurdivisie van 'n finansiële instelling.

Die sekondêre doelwit van die studie is om vas te stel of enige biografiese veranderlikes hierdie verband tussen werknemertevredenheid en organisasie-verbondenheid medieer.

\section{NAVORSINGSONTWERP}

\section{Navorsingsbenadering}

Die paradigmatiese uitgangspunt van hierdie studie is kwantitatief, terwyl die studie in terme van die tyddimensie tipies as 'n dwarssnitstudie beskryf kan word. Data-insameling het aan die hand van 'n veldopname geskied en die ontleding van die data kan weer as korrelasioneel en ex post facto beskryf word.

\section{Navorsingsmetodologie}

Die navorsingsmetodologie wat in hierdie studie gevolg is, sal aan die hand van die volgende vier hoofde bespreek word:

\section{Deelnemers aan studie}

Die studie is uitgevoer binne die mensbestuursdivisie van 'n finansiële instelling. Die 300 persone (Patterson B-, C- en Dbande) wat genader is om deel te neem aan die studie vorm die steekproefraamwerk. 'n Gerieflikheidsteekproef het 167 vraelyste opgelewer ('n responskoers van 55\%), waarvan 145 volledig voltooi was en vir finale ontleding gebruik is. Die biografiese inligting van die respondente lyk soos volg:
TABEL 1

BIOGRAFIESE BESONDERHEDE VAN RESPONDENTE

\begin{tabular}{|c|c|c|}
\hline Posband & Frekwensie & Persentasie \\
\hline $\mathrm{CC} / \mathrm{TT}$ & 66 & $43,70 \%$ \\
\hline $\mathrm{MM} / \mathrm{PP}$ & 85 & $56,30 \%$ \\
\hline Totaal & 151 & $100,00 \%$ \\
\hline Geslag & Frekwensie Persentasie & \\
\hline Manlik & 43 & $25,70 \%$ \\
\hline Vroulik & 124 & $74,30 \%$ \\
\hline Totaal & 167 & $100,00 \%$ \\
\hline Taal & Frekwensie Persentasie & \\
\hline Afrikaans & 98 & $61,30 \%$ \\
\hline Engels & 62 & $38,80 \%$ \\
\hline Total & 160 & $100,00 \%$ \\
\hline Kwalifikasie & Frekwensie Persentasie & \\
\hline Matriek & 48 & $30,20 \%$ \\
\hline Diploma & 26 & $16,40 \%$ \\
\hline Graad & 33 & $20,80 \%$ \\
\hline Na-graads & 52 & $32,70 \%$ \\
\hline Totaal & 159 & $100,00 \%$ \\
\hline Jare diens & Frekwensie Persentasie & \\
\hline $0-3$ & 28 & $17,20 \%$ \\
\hline $3-5$ & 28 & $17,20 \%$ \\
\hline Meer as 5 & 107 & $65,60 \%$ \\
\hline Totaal & 163 & $100,00 \%$ \\
\hline
\end{tabular}

Nota: Totale varieer as gevolg van ontbrekende response.

Dit blyk uit tabel 1 dat die meeste respondente in Patterson Dband gekategoriseer is $(56,3 \%)$; vroulik is $(74,3 \%)$; Afrikaanssprekend is $(61,3 \%)$; oor na-graadse kwalifikasies beskik $(32,7 \%)$ en meer as 5 jaar diens het $(65,6 \%)$.

Meetinstrumente

Die volgende twee instrumente is vir hierdie studie gebruik:

Werknemertevredenheidsvraelys (MSQ20) (Weiss, Dawes, England \& Lofquist, 1967)

Die Minnesota Satisfaction Questionnaire (MSQ) van Weiss, Dawes, England en Lofquist (1967) is gebruik in die meting van werknemertevredenheid. Die verkorte weergawe van die MSQ is in hierdie studie gebruik. Dit bestaan uit 20 items wat die respondent se tevredenheid/ontevredenheid met 'n aantal veranderlikes meet en maak gebruik van 'n vyfpunteresponsskaal.

Die instrument meet tevredenheid/ontevredenheid met vaardigheidaanwending, prestasie, aktiwiteit, bevordering, gesag, maatskappybeleid en -praktyke, kreatiwiteit, onafhanklikheid, morele waardes, erkenning, verantwoordelikheid, sekuriteit, toesighouding - tegnies, verskeidenheid en werksomstandighede. Die totale telling behaal, bied ' $n$ aanduiding van die respondent se algemene tevredenheid/ontevredenheid met sy werk en sal gebruik word om vlakke van werknemertevredenheid te operasionaliseer.

Die betroubaarheid van die instrument: Kaplan (1990) het 'n betroubaarheidskoëffisiënt van 0,90 van die som van die 20 items gerapporteer. Welman en Basson (1995) het 'n alfakoëffisiënt van 0,92 gerapporteer.

Die geldigheid van die instrument: Volgens Welman en Basson (1995) is geldigheidskoëffisiënte, wat tussen 0,49 en 0,70 wissel, op vier van die instrument se skale gerapporteer. In 'n SuidAfrikaanse steekproef van 1791 professionele persone het Kaplan (1990) gevind dat die faktore van die verkorte weergawe konseptueel betekenisvol en onderskeibaar is. 
Organisasieverbondenheidsvraelys (Roodt, 1997)

'n Verskeidenheid instrumente is in die verlede ontwikkel in 'n poging om die konstruk te meet (Akhtar \& Chan, 1997; Allen \& Meyer; 1990; Brown, 1996; Hrebiniak \& Alutto, 1972; Reichers, 1985, soos geïdentifiseer in Roodt, 1991).

Die instrument wat gebruik is, is aanvanklik deur Roodt (1997) ontwikkel. Ses skale (139 items in totaal) is ontwikkel ten einde ses werkverwante fokusse as kognitiewe predisposisies te operasionaliseer. Betrokkenheid is in die volgende fokusse gemeet, naamlik werk, pos, beroep, loopbaan, unie en organisasie. 'n Faktorontleding van die 139 items het vier duidelik gedefinieerde skale na vore gebring, naamlik 'n werkbeheptheid-, organisasie-verwante verbondenheid-, unieverbondenheid- en werkvervreemdingskaal. Vir die doel van hierdie studie is die 38 -item organisasie-verwante verbondenheidskaal gebruik.

Itemresponsskale is op 'n vyfpunt-intensiteitskaal gemeet en wissel van een (in 'n baie klein mate) tot vyf (in 'n baie groot mate), waar slegs die ekstreme pole gedefinieer is. Slegs ' $n$ Engelse vraelys is aan die respondente verskaf.

Betroubaarheid van die instrument: Vir die doel van hierdie studie is slegs die organisasie-verwante verbondenheidskaal (Roodt, 1997) as meetinstrument gebruik. Die Cronbach alfakoëffisiënt vir hierdie skaal, met 38 items, word aangedui as 0,914 . Storm en Roodt (2002) het gerapporteer dat, nadat vier items uit die organisasie-verwante verbondenheidsvraelys weggelaat is, slegs een faktor met 'n hoë alfa-koëffisiënt $(0,94)$ verkry is.

Geldigheid van die instrument: Die hoë betroubaarheid $(0,94)$ bevestig oënskynlik dat die onderskeid tussen fokusse (werk, pos, beroep, loopbaan en organisasie) slegs van teoretiese belang mag wees. Dit blyk of die instrument goed daarin slaag om die konstruk organisasieverbondenheid te meet.

\section{Prosedure}

Vraelyste is elektronies via die intranet aan deelnemers per e-pos versend. Die vraelyste is vergesel van 'n dekbrief waarin die doel van die studie verduidelik is. ' $n$ Vraelys is ook ingesluit om die nodige biografiese inligting te verkry. Respondente is versoek om vraelyste via e-pos terug te besorg. Deelname aan die projek was vrywillig. Genoeg tyd is toegelaat sodat alle deelnemers die vraelyste gemaklik kon voltooi. Waar items onvoltooid gelaat is, is die vraelys as ongeskik vir verwerking geag. Respondente is van die vertroulike hantering asook anonimiteit van hul response verseker.

\section{Statistiese verwerking}

Die Statistiese Konsultasiediens van die Randse Afrikaanse Universiteit het die statistiese verwerking rekenaarmatig met behulp van die SPSS Windows-pakket uitgevoer. Die prosedure wat met die iteratiewe itemontleding gevolg is, is op Gulliksen (1950) se benadering gebaseer wat die NP50-program van die Nasionale Instituut vir Personeelnavorsing (NIPN) hiervoor gebruik het.

\section{RESULTATE}

Die eerste fase van die data-ontleding behels die volgende:

Die itemtellings van die werknemertevredenheidskaal en organisasie-verbondenheidskaal is gefaktoranaliseer (op twee vlakke) met 'n prosedure soos voorgestel deur Schepers (1992), ten einde die faktorstruktuur van die instrument te bepaal. Die ontleding van die werktevredenheidvraelys word eerste bespreek.

Ten einde die toepaslikheid van die item-interkorrelasiematriks vir faktorontleding te bepaal, is die Kaiser-Meyer-Olkin (KMO) Maatstaf vir Steekproeftoereikendheid (MSA) en Bartlett se
Toets van Sferisiteit op die matriks toegepas. Die KMO lewer 'n MSA van 0,875 op en die Bartlett toets vir Sferisiteit 'n chikwadraat van $1353,877(p=0,0000)$. Die waardes is op aanvaarbare vlak en die matriks is dus gepas vir verdere faktorontleding.

Hierna is die 20 items van die werknemertevredenheidsvraelys geïnterkorreleer. Eigenwaardes is bereken en vier eigenwaardes groter as een is verkry en vier faktore word gepostuleer volgens Kaiser (1970) se kriterium. Hierdie vier faktore verklaar ongeveer $60 \%$ van die variansie in die faktor ruimte.

TABEL 2

EIGENWAARDES VAN DIE ONGEREDUSEERDE ITEM INTER-KORRELASIE MATRIKS (20 X 20) VAN DIE MSQ20

\begin{tabular}{|c|c|c|c|}
\hline \multicolumn{4}{|c|}{ Eigenwaardes } \\
\hline Items & Totaal & $\%$ variansie & Kumulatiewe \% \\
\hline 1 & 7,525 & 37,627 & 37,627 \\
\hline 2 & 1,883 & 9,414 & 47,042 \\
\hline 3 & 1,275 & 6,374 & 53,416 \\
\hline 4 & 1,222 & 6,111 & 59,527 \\
\hline 5 & 0,947 & 4,733 & 64,259 \\
\hline 6 & 0,884 & 4,418 & 68,677 \\
\hline 7 & 0,785 & 3,925 & 72,602 \\
\hline 8 & 0,722 & 3,611 & 76,213 \\
\hline 9 & 0,672 & 3,36 & 79,573 \\
\hline 10 & 0,649 & 3,247 & 82,82 \\
\hline 11 & 0,563 & 2,817 & 85,637 \\
\hline 12 & 0,488 & 2,441 & 88,077 \\
\hline 13 & 0,43 & 2,149 & 90,227 \\
\hline 14 & 0,394 & 1,972 & 92,199 \\
\hline 15 & 0,358 & 1,79 & 93,989 \\
\hline 16 & 0,336 & 1,679 & 95,668 \\
\hline 17 & 0,29 & 1,45 & 97,118 \\
\hline 18 & 0,235 & 1,176 & 98,294 \\
\hline 19 & 0,2 & 1,002 & 99,297 \\
\hline 20 & 0,141 & 0,703 & 100 \\
\hline
\end{tabular}

Spoor $=20$

Die itemladings op die vier gepostuleerde faktore word voorgestel in Tabel 3. Die ladings word in vetgedrukte letters voorgestel vir elk van die faktore. Slegs items met waardes groter as 0,3 is in hierdie gesorteerde en geroteerde matriks ingesluit.

Die tweedevlak faktorontleding is op die volgende wyse uitgevoer. Subtellings op elkeen van die gepostuleerde faktore is verkry deur itemtellings te sommeer. Hierdie subtellings is weer geïnterkorreleer en die resultate word in Tabel 4 weergegee.

Die KMO lewer 'n MSA van 0,765 op en die Bartlett-toets vir Sferisiteit 'n chi-kwadraat van 199,971 ( $\mathrm{p}=0,0000)$. Die waardes is op aanvaarbare vlak en is die matriks dus gepas vir verdere faktorontleding.

Eigenwaardes is weer bereken op die subtellings van die interkorrelasie matriks. Slegs een faktor is gepostuleer volgens Kaiser (1970) se kriterium (eigenwaardes groter as 1) en verduidelik ongeveer $64 \%$ van die variansie in die faktor-ruimte. Die resultate verskyn in Tabel 5 . 
TABEL 3

ITEMLADINGS OP VIER GEPOSTULEERDE FAKTORE VAN DIE MSQ20

\begin{tabular}{|c|c|c|c|c|}
\hline \multicolumn{5}{|c|}{ Faktor } \\
\hline Items & 1 & 2 & 3 & 4 \\
\hline C19 & 0,66 & & & 0,391 \\
\hline C13 & 0,629 & & & \\
\hline C14 & 0,623 & & & \\
\hline C17 & 0,563 & & & 0,329 \\
\hline C18 & 0,502 & & & \\
\hline C12 & 0,452 & & & \\
\hline C4 & 0,313 & & & \\
\hline C3 & & 0,778 & & \\
\hline C2 & & 0,638 & & \\
\hline C1 & & 0,628 & & \\
\hline C20 & 0,48 & 0,521 & & \\
\hline C10 & & & 0,668 & \\
\hline C15 & & 0,338 & 0,57 & 0,412 \\
\hline C11 & & 0,481 & 0,556 & \\
\hline C9 & & & 0,546 & \\
\hline C8 & 0,343 & & 0,49 & \\
\hline C16 & & 0,409 & 0,46 & 0,382 \\
\hline C7 & & & 0,377 & \\
\hline C5 & & & & 0,841 \\
\hline C6 & 0,395 & & & 0,705 \\
\hline
\end{tabular}

Faktore is onttrek deur middel van hoofas faktorontleding. Rotasie metode: Varimax met Kaiser normalisering. Gekonvergeer in vyf iterasies.

Ladings $<0,3$ is verwyder.

TABEL 4

INTER-KORRELASIEMATRIKS VAN SUBTELLINGS VAN DIE MSQ20

\begin{tabular}{lcccc}
\hline & Subtelling 1 & Subtelling 2 & Subtelling 3 & Subtelling 4 \\
\hline Subtelling 1 & 1 & 0,465 & 0,59 & 0,567 \\
Subtelling 2 & 0,465 & 1 & 0,617 & 0,377 \\
Subtelling 3 & 0,59 & 0,617 & 1 & 0,529 \\
Subtelling 4 & 0,567 & 0,377 & 0,529 & 1 \\
\hline
\end{tabular}

TABEL 5

EIGENWAARDES VAN DIE SUB-TELLING INTERKORRELASIEMATRIKS VAN DIE MSQ20

\begin{tabular}{lccc}
\hline \multicolumn{3}{c}{ Inisiële Eigenwaardes } \\
\hline Faktor & Totaal & \% variansie & Kumulatiewe \% \\
1 & 2,578 & 64,449 & 64,449 \\
2 & 0,661 & 16,531 & 80,98 \\
3 & 0,419 & 10,469 & 91,449 \\
4 & 0,342 & 8,551 & 100 \\
\hline
\end{tabular}

Die ladings van subtellings op die enkele faktor verskyn in Tabel 6 .

Iteratiewe itemontledings is uitgevoer op die enkele verkrygde skaal. Die item-toets korrelasie sowel as die toetsbetroubaarheid (Cronbach Alfa) met die spesifieke item uitgelaat, verskyn in tabel 7. Die verkrygde skaal gee 'n Cronbach Alfa van 0,91 weer.
TABEL 6

ONGEROTEERDE FAKTOR-MATRIKS VAN DIE MSO20 SUBTELLINGS

\begin{tabular}{lcc}
\hline Subtellings & Faktor $\mathbf{1}$ & Kommunaliteite $\mathbf{h j}^{\mathbf{2}}$ \\
\hline Subtelling 3 & 0,838 & 0,703 \\
Subtelling 1 & 0,749 & 0,561 \\
Subtelling 4 & 0,658 & 0,433 \\
Subtelling 2 & 0,656 & 0,430 \\
\hline
\end{tabular}

Faktore is onttrek deur hoofas faktorontleding. Gekonvergeer in nege iterasies.

TABEL 7

ITEM BETROUBAARHEIDSTATISTIEK VIR DIE MSQ20

\begin{tabular}{|c|c|c|c|c|}
\hline & \multicolumn{4}{|c|}{ Item-totaal Statistiek } \\
\hline & $\begin{array}{c}\text { Skaal } \\
\text { Gemiddeld } \\
\text { Indien item } \\
\text { uitgelaat }\end{array}$ & $\begin{array}{c}\text { Skaal Variansie } \\
\text { indien item } \\
\text { uitgelaat }\end{array}$ & $\begin{array}{c}\text { Korrekte Item } \\
\text { Totale } \\
\text { Korrelasie }\end{array}$ & $\begin{array}{c}\text { Alpha indien } \\
\text { item } \\
\text { uitgelaat }\end{array}$ \\
\hline $\mathrm{C} 1$ & 52,1586 & 74,6622 & 0,3867 & 0,9073 \\
\hline $\mathrm{C} 2$ & 52,3310 & 72,9591 & 0,4853 & 0,9052 \\
\hline C3 & 52,4897 & 71,6544 & 0,5529 & 0,9035 \\
\hline $\mathrm{C} 4$ & 52,7724 & 72,0798 & 0,5231 & 0,9043 \\
\hline C5 & 52,6897 & 71,0905 & 0,6000 & 0,9023 \\
\hline C6 & 52,7793 & 70,6037 & 0,6087 & 0,9020 \\
\hline $\mathrm{C} 7$ & 52,4897 & 73,9461 & 0,4527 & 0,9058 \\
\hline C8 & 53,0345 & 72,3530 & 0,5022 & 0,9048 \\
\hline C9 & 52,7172 & 72,9125 & 0,5472 & 0,9037 \\
\hline C10 & 53,0621 & 73,5725 & 0,4523 & 0,9059 \\
\hline C11 & 52,5931 & 70,5347 & 0,6675 & 0,9005 \\
\hline $\mathrm{C} 12$ & 52,9172 & 72,8820 & 0,3896 & 0,9085 \\
\hline $\mathrm{C} 13$ & 53,3724 & 72,2770 & 0,5265 & 0,9042 \\
\hline C14 & 53,3931 & 72,4625 & 0,4833 & 0,9054 \\
\hline C15 & 52,5862 & 71,2581 & 0,7185 & 0,9000 \\
\hline C16 & 52,5586 & 70,8038 & 0,7213 & 0,8996 \\
\hline C17 & 52,7172 & 71,0514 & 0,5928 & 0,9025 \\
\hline C18 & 52,8276 & 72,4631 & 0,5004 & 0,9049 \\
\hline C19 & 52,8828 & 71,2987 & 0,6184 & 0,9019 \\
\hline $\mathrm{C} 20$ & 52,7172 & 70,5653 & 0,6767 & 0,9004 \\
\hline
\end{tabular}

Betroubaarheidkoëffisiënt $\mathrm{N}=145 ; \mathrm{N}$ items $=20$; Alpha $=0,91$

Resultate met betrekking tot die Organisasieverbondenheidskaal word vervolgens bespreek:

Ten einde die toepaslikheid van die item-interkorrelasiematriks vir faktorontleding te bepaal, is die Kaiser-Meyer-Olkin (KMO) Maatstaf vir Steekproeftoereikendheid (MSA) en Bartlett se Toets van Sferisiteit op die matriks toegepas. Die KMO lewer 'n MSA van 0,903 op en die Bartlett-toets 'n chi-kwadraat van 4635,110 $(p=0,0000)$. Die waardes is op 'n aanvaarbare vlak en die matriks is dus gepas vir verdere faktorontleding. Item 6 is vir verdere verwerkings uitgelaat.

Die 38 items van die Organisasieverbondenheidsvraelys is geïnterkorreleer. Eigenwaardes is op die ongereduseerde iteminterkorrelasiematriks bereken en 6 eigenwaardes groter as een is verkry volgens Kaiser (1960) se kriterium en word gerapporteer in tabel 8. Hierdie 6 faktore verduidelik ongeveer $69 \%$ van die variansie in die faktor faktorruimte.

Die itemladings op die 6 gepostuleerde faktore word voorgestel in Tabel 9. Die ladings word in vetgedrukte letters voorgestel vir elk van die faktore. Slegs items met waardes groter as 0,3 is in hierdie gesorteerde matriks ingesluit. 
TABEL 8

EIGENWAARDES VAN DIE ONGEREDUSEERDE ITEMINTERKORRELASIEMATRIKS (37 X 37) VAN DIE ORGANISASIEVERBONDENHEIDSKAAI

\begin{tabular}{|c|c|c|c|}
\hline \multirow[b]{2}{*}{ Item } & \multicolumn{3}{|c|}{ Inisiële eigenwaardes } \\
\hline & Totaal & $\%$ variansie & Kumulatiewe \% \\
\hline 1 & 13,785 & 37,256 & 37,256 \\
\hline 2 & 3,882 & 10,491 & 47,748 \\
\hline 3 & 2,717 & 7,344 & 55,092 \\
\hline 4 & 2,011 & 5,435 & 60,527 \\
\hline 5 & 1,914 & 5,173 & 65,7 \\
\hline 6 & 1,127 & 3,047 & 68,747 \\
\hline 7 & 0,969 & 2,618 & 71,365 \\
\hline 8 & 0,938 & 2,534 & 73,899 \\
\hline 9 & 0,844 & 2,28 & 76,179 \\
\hline 10 & 0,74 & 2,001 & 78,18 \\
\hline 11 & 0,71 & 1,92 & 80,099 \\
\hline 12 & 0,661 & 1,785 & 81,884 \\
\hline 13 & 0,625 & 1,688 & 83,573 \\
\hline 14 & 0,522 & 1,412 & 84,985 \\
\hline 15 & 0,49 & 1,323 & 86,308 \\
\hline 16 & 0,448 & 1,21 & 87,518 \\
\hline 17 & 0,44 & 1,19 & 88,708 \\
\hline 18 & 0,423 & 1,143 & 89,85 \\
\hline 19 & 0,38 & 1,026 & 90,877 \\
\hline 20 & 0,333 & 0,899 & 91,776 \\
\hline 21 & 0,316 & 0,855 & 92,631 \\
\hline 22 & 0,297 & 0,804 & 93,435 \\
\hline 23 & 0,275 & 0,742 & 94,177 \\
\hline 24 & 0,251 & 0,677 & 94,855 \\
\hline 25 & 0,24 & 0,649 & 95,504 \\
\hline 26 & 0,21 & 0,567 & 96,071 \\
\hline 27 & 0,2 & 0,542 & 96,613 \\
\hline 28 & 0,182 & 0,491 & 97,103 \\
\hline 29 & 0,176 & 0,475 & 97,578 \\
\hline 30 & 0,162 & 0,438 & 98,016 \\
\hline 31 & 0,156 & 0,423 & 98,439 \\
\hline 32 & 0,13 & 0,352 & 98,791 \\
\hline 33 & 0,118 & 0,319 & 99,111 \\
\hline 34 & 0,09 & 0,263 & 99,374 \\
\hline 35 & 0,08 & 0,238 & 99,612 \\
\hline 36 & 0,07 & 0,21 & 99,822 \\
\hline 37 & 0,06 & 0,178 & 100 \\
\hline
\end{tabular}

Spoor $=37$

Die tweedevlak faktorontleding is op die volgende wyse uitgevoer. Subtellings op elkeen van die gepostuleerde faktore is verkry deur itemtellings te sommeer. Hierdie subtellings is weer geinterkorreleer en die resultate word in Tabel 10 weergegee.

Ten einde die toepaslikheid van die item-interkorrelasiematriks vir faktorontleding te bepaal, is die Kaiser-MeyerOlkin (KMO) Maatstaf vir Steekproeftoereikendheid en Bartlett se Toets van Sferisiteit op die matriks toegepas. Die KMO lewer 'n MSA van 0,738 op en die Bartlett-toets vir Sferisiteit 'n chi-kwadraat van 287,858 ( $\mathrm{p}=0,0000)$. Die waardes is op aanvaarbare vlak en die matriks is dus gepas vir verdere faktorontleding.

Eigenwaardes is bereken op die subtellings van die interkorrelasie matriks. Twee faktore is gepostuleer volgens Kaiser (1960) se kriterium (eigenwaardes groter as 1) en verklaar ongeveer $66 \%$ van die variansie in die faktorruimte. Die resultate verskyn in Tabel 11.
TABEL 9

ITEMLADINGS OP SES GEPOSTULEERDE FAKTORE $(6$ x 6$)$ VAN DIE ORGANISASIEVERBONDENHEIDSKAAL

\begin{tabular}{|c|c|c|c|c|c|c|}
\hline \multirow[b]{2}{*}{ Subtellings } & \multicolumn{6}{|c|}{ Faktor } \\
\hline & 1 & 2 & 3 & 4 & 5 & 6 \\
\hline D31 & 0,779 & 0,184 & 0,149 & 0,127 & 0,211 & \\
\hline D27 & 0,753 & 0,228 & 0,289 & 0,231 & & \\
\hline D29 & 0,739 & 0,211 & 0,104 & & 0,283 & 0,15 \\
\hline D36 & 0,694 & 0,3 & & & & 0,115 \\
\hline D35 & 0,633 & 0,303 & 0,202 & & 0,198 & $-0,132$ \\
\hline D21 & 0,629 & 0,252 & 0,141 & & 0,229 & 0,362 \\
\hline D30 & 0,628 & 0,218 & & & 0,265 & 0,33 \\
\hline D23 & 0,548 & 0,164 & 0,104 & & 0,38 & 0,397 \\
\hline D25 & 0,545 & 0,249 & & & 0,332 & 0,224 \\
\hline D28 & 0,515 & 0,158 & 0,184 & 0,209 & 0,252 & \\
\hline D26 & 0,449 & 0,242 & 0,19 & & 0,265 & 0,131 \\
\hline D1 & 0,37 & 0,337 & 0,212 & & & 0,256 \\
\hline D3 & 0,136 & 0,832 & 0,114 & 0,12 & 0,2 & \\
\hline D9 & 0,248 & 0,792 & 0,216 & & 0,117 & \\
\hline D8 & 0,184 & 0,777 & 0,207 & 0,19 & 0,193 & \\
\hline D10 & 0,28 & 0,753 & 0,241 & & & 0,201 \\
\hline D12 & 0,288 & 0,712 & 0,382 & & 0,116 & 0,17 \\
\hline D4 & 0,3 & 0,642 & 0,152 & & & 0,114 \\
\hline D11 & 0,483 & 0,51 & 0,242 & & & 0,179 \\
\hline D5 & 0,243 & 0,51 & 0,101 & & 0,324 & \\
\hline D34 & 0,293 & 0,508 & 0,238 & 0,181 & 0,375 & \\
\hline D13 & 0,293 & 0,481 & 0,232 & & & 0,415 \\
\hline D18 & 0,261 & 0,215 & 0,853 & 0,114 & & \\
\hline D15 & 0,245 & 0,325 & 0,777 & & & 0,112 \\
\hline D16 & 0,206 & 0,27 & 0,758 & 0,164 & 0,105 & \\
\hline D19 & 0,412 & 0,191 & 0,667 & & & 0,111 \\
\hline D20 & $-0,1$ & 0,149 & 0,555 & & 0,131 & \\
\hline D14 & 0,13 & & & 0,916 & & \\
\hline D17 & & & 0,163 & 0,908 & & \\
\hline D7 & & & & 0,86 & & \\
\hline D2 & & 0,186 & & 0,818 & & \\
\hline D37 & 0,209 & & & & 0,748 & \\
\hline D22 & & 0,131 & & $-0,113$ & 0,737 & 0,164 \\
\hline D38 & 0,388 & 0,184 & 0,191 & 0,102 & 0,732 & \\
\hline D32 & 0,373 & & 0,114 & & 0,67 & $-0,117$ \\
\hline D33 & $-0,101$ & $-0,142$ & & 0,164 & $-0,35$ & $-0,158$ \\
\hline D24 & 0,373 & 0,154 & & & 0,105 & 0,487 \\
\hline
\end{tabular}

Faktore is onttrek deur hoofasfaktorontleding. Rotasiemetode: Varimax met Kaiser normalisering. Gekonvergeer in sewe iterasies.

TABEL 10

SUB-TELLING INTER-KORRELASIEMATRIKS (6 x 6) VAN DIE ORGANISASIEVERBONDENHEIDSKAAL

\begin{tabular}{lrrrrrr}
\hline & ST 1 & ST 2 & ST 3 & ST 4 & ST 5 & ST 6 \\
\hline ST 1 & 1 & 0,69 & 0,483 & 0,154 & 0,563 & 0,494 \\
ST 2 & 0,69 & 1 & 0,582 & 0,229 & 0,405 & 0,359 \\
ST 3 & 0,483 & 0,582 & 1 & 0,225 & 0,213 & 0,245 \\
ST 4 & 0,154 & 0,229 & 0,225 & 1 & $-0,02$ & $-0,046$ \\
ST 5 & 0,563 & 0,405 & 0,213 & $-0,02$ & 1 & 0,23 \\
ST 6 & 0,494 & 0,359 & 0,245 & $-0,046$ & 0,23 & 1 \\
\hline
\end{tabular}

ST $=$ Subtelling 
TABEL 11

EIGENWAARDES VAN DIE SUB-TELLING INTERKORRELASIEMATRIKS VAN DIE ORGANISASIEVERBONDHEIDSKAAL

\begin{tabular}{lccc}
\hline & \multicolumn{3}{c}{ Eigenwaardes } \\
\hline Subtelling & Totaal & \% variansie & Kumulatiewe \% \\
\hline 1 & 2,803 & 46,712 & 46,712 \\
2 & 1,131 & 18,848 & 65,56 \\
3 & 0,781 & 13,01 & 78,57 \\
4 & 0,658 & 10,962 & 89,532 \\
5 & 0,374 & 6,241 & 95,772 \\
6 & 0,254 & 4,228 & 100 \\
\hline
\end{tabular}

Spoor $=6$

Twee faktore is onttrek deur middel van hoofas-faktorontleding. Die ladings van sub-tellings op hierdie twee faktore verskyn in tabel 12 .

TABEL 12

SUB-TELLINGLADINGS OP DIE TWEE FAKTORE VAN DIE ORGANISASIEVERBONDENHEIDSKAAI

\begin{tabular}{lcc}
\hline & \multicolumn{2}{c}{ Faktor } \\
\hline Subtelling & $\mathbf{1}$ & $\mathbf{2}$ \\
\hline Subtelling 1 & $\mathbf{0 , 9 0 5}$ & 0,114 \\
Subtelling 5 & $\mathbf{0 , 6 0 8}$ & \\
Subtelling 2 & $\mathbf{0 , 5 6 3}$ & 0,484 \\
Subtelling 6 & $\mathbf{0 , 5 1 5}$ & \\
Subtelling 3 & 0,302 & $\mathbf{0 , 5 3 4}$ \\
Subtelling 4 & & $\mathbf{0 , 4 4 3}$ \\
\hline
\end{tabular}

Faktore is onttrek deur hoofas faktorontleding. Rotasie metode: Oblimin met Kaiser normalisering. Gekonvergeer in ses iterasies.

Die tellings van die twee skale is geïnterkorreleer en die resultate word weergegee in tabel 13.

TABEL 13

FAKTOR INTERKORRELASIE-MATRIKS

\begin{tabular}{lcc}
\hline Faktor & 1 & $\mathbf{2}$ \\
\hline 1 & 1,000 & 0,311 \\
2 & 0,311 & 1,000 \\
\hline
\end{tabular}

Faktore is onttrek deur hoofas faktorontleding. Rotasie metode: Oblimin met Kaiser normalisering

'n Iteratiewe itemontleding is gedoen op die Organisasieverbondenheidskaal. Die item-toets korrelasies sowel as die toetsbetroubaarheid (Cronbach Alfa) van die betrokke item verskyn in tabel 14. Die verkreë enkele skaal lewer 'n Cronbach Alfa van 0,95 . Die beskrywende statistiek word in Tabel 14 gerapporteer.

'n Interatiewe itemontleding is gedoen op die Loopbaanverbondenheidskaal. Die item-toets korrelasies sowel as die toetsbetroubaarheid (Cronbach Alfa) van die betrokke items verskyn in tabel 15. Die verkreë enkele skaal lewer 'n Cronbach Alfa van 0,85 . Die beskrywende statistiek word in Tabel 15 gerapporteer.
TABEL 14

ITEMBETROUBAARHEIDSTATISTIEK VIR DIE ORGANISASIEVERBONDENHEIDSKAAL

\begin{tabular}{|c|c|c|c|c|}
\hline & $\begin{array}{l}\text { Skaal } \\
\text { Gemiddeld } \\
\text { Indien item } \\
\text { uitgelaat }\end{array}$ & $\begin{array}{l}\text { Skaal } \\
\text { Variansie } \\
\text { indien item } \\
\text { uitgelaat }\end{array}$ & $\begin{array}{l}\text { Item } \\
\text { Totale } \\
\text { Korrelasie } \\
\text { indien } \\
\text { uitgelaat }\end{array}$ & $\begin{array}{l}\text { Alfa } \\
\text { Koëffisient } \\
\text { indien item } \\
\text { uitgelaat }\end{array}$ \\
\hline D31 & 77,8827 & 165,3837 & 0,7235 & 0,9450 \\
\hline D27 & 78,0556 & 165,6677 & 0,7366 & 0,9449 \\
\hline D29 & 77,6049 & 164,5635 & 0,7572 & 0,9446 \\
\hline D36 & 77,7407 & 168,0939 & 0,6286 & 0,9460 \\
\hline D35 & 77,9259 & 165,8330 & 0,6622 & 0,9457 \\
\hline D21 & 77,3519 & 165,1487 & 0,7267 & 0,9449 \\
\hline D30 & 77,5185 & 164,7108 & 0,7132 & 0,9451 \\
\hline D23 & 77,6728 & 166,0103 & 0,7001 & 0,9452 \\
\hline D25 & 77,5309 & 165,1450 & 0,6675 & 0,9456 \\
\hline D28 & 78,0123 & 168,0247 & 0,5850 & 0,9465 \\
\hline D26 & 77,7407 & 168,8516 & 0,6030 & 0,9463 \\
\hline D1 & 77,0802 & 173,3910 & 0,4836 & 0,9474 \\
\hline D37 & 78,5556 & 168,7578 & 0,4567 & 0,9484 \\
\hline D22 & 78,2963 & 169,5017 & 0,4384 & 0,9485 \\
\hline D38 & 78,1296 & 165,1322 & 0,7051 & 0,9452 \\
\hline D32 & 78,4568 & 168,2373 & 0,5447 & 0,9470 \\
\hline D33I & 77,7284 & 175,4661 & 0,3132 & 0,9488 \\
\hline D3 & 77,3086 & 170,4259 & 0,6021 & 0,9463 \\
\hline D9 & 77,1914 & 170,5159 & 0,6648 & 0,9459 \\
\hline D8 & 77,3333 & 170,9689 & 0,6380 & 0,9462 \\
\hline D10 & 77,2222 & 168,9441 & 0,6840 & 0,9456 \\
\hline D12 & 77,2778 & 168,4503 & 0,7073 & 0,9454 \\
\hline D4 & 77,0864 & 171,7937 & 0,5830 & 0,9466 \\
\hline D11 & 77,2963 & 167,9738 & 0,6657 & 0,9457 \\
\hline D5 & 77,4506 & 170,5472 & 0,5947 & 0,9464 \\
\hline D34 & 77,4938 & 169,5186 & 0,6626 & 0,9458 \\
\hline D13 & 77,2222 & 170,3478 & 0,5798 & 0,9465 \\
\hline D24 & 77,0000 & 171,1304 & 0,4630 & 0,9477 \\
\hline
\end{tabular}

Betroubaarheidskoëffisiënt $\mathrm{N}=162 ; \mathrm{N}$ Items $=28 ;$ Alpha $=0,9480$

TABEL 15

ITEMBETROUBAARHEIDSTATISTIEK VIR DIE LOOPBA ANVERBONDENHEIDSK AAL

\begin{tabular}{lllll}
\hline & $\begin{array}{l}\text { Skaal } \\
\text { Gemiddeld } \\
\text { Indien item } \\
\text { uitgelaat }\end{array}$ & $\begin{array}{l}\text { Skaal } \\
\text { Variansie } \\
\text { indien item } \\
\text { uitgelaat }\end{array}$ & $\begin{array}{l}\text { Korrekte } \\
\text { Item- } \\
\text { Totale } \\
\text { Korrelasie }\end{array}$ & $\begin{array}{l}\text { Alfa } \\
\text { indien item } \\
\text { uitgelaat }\end{array}$ \\
\hline D18 & 19,5215 & 22,9795 & 0,5866 & 0,8372 \\
D15 & 19,4110 & 23,4288 & 0,4953 & 0,8447 \\
D16 & 19,5828 & 23,1459 & 0,5889 & 0,8374 \\
D19 & 9,4785 & 23,7573 & 0,4641 & 0,8473 \\
D20 & 20,0982 & 24,8051 & 0,3595 & 0,8551 \\
D14 & 20,5521 & 19,8908 & 0,7041 & 0,8227 \\
D17 & 20,5951 & 19,9708 & 0,7259 & 0,8199 \\
D7 & 20,5399 & 20,9413 & 0,6099 & 0,8340 \\
D2 & 20,4908 & 20,5724 & 0,6358 & 0,8311 \\
\hline
\end{tabular}

Betroubaarheidskoëffisient $\mathrm{N}=163 ; \mathrm{N}$ items $=9$; Alpha $=0,8528$

Ten einde die gestelde doelwitte van die studie te toets, word die volgende resultate in Tabel 16 gerapporteer. 
TABEL 16

INTERKORRELASIES TUSSEN KONSTRUKTE

\begin{tabular}{lccc}
\hline & $\begin{array}{c}\text { Werknemer- } \\
\text { Tevredenheid }\end{array}$ & $\begin{array}{c}\text { Organisasie- } \\
\text { verbondenheid }\end{array}$ & $\begin{array}{c}\text { Loopbaan- } \\
\text { verbondenheid }\end{array}$ \\
\hline $\begin{array}{l}\text { Werknemertevredenheid } \\
\text { (Faktor 1) }\end{array}$ & 1,000 & $0,650^{* *}$ & $0,253^{* *}$ \\
P (2-kantig) & & 0,000 & 0,003 \\
$\mathbf{N}$ & 145 & 141 & 140 \\
$\begin{array}{l}\text { Organisasieverbondenheid } \\
\text { (Faktor 1) }\end{array}$ & $0,650^{* *}$ & 1,000 & $0,411^{* *}$ \\
P (2-kantig) & 0,000 & & 0,000 \\
$\mathbf{N}$ & 141 & 162 & 158 \\
$\begin{array}{l}\text { Loopaanverbondenheid } \\
\text { (Faktor 2) }\end{array}$ & $0,253^{* *}$ & $0,411^{* *}$ & 1,000 \\
P (2-kantig) & 0,003 & 0,000 & \\
$\mathbf{N}$ & 140 & 158 & 163 \\
\hline
\end{tabular}

** Korrelasie is beduidend by die 0,01 peil (2-kantig)

Uit die tabel blyk dit dat daar ' $n$ statisties-beduidende korrelasies bestaan tussen werknemertevredenheid en Organisasieverbondenheid $(\mathrm{r}=0,650 ; \mathrm{p}=0,000)$; tussen Werknemertevredenheid en Loopbaanverbondenheid $(r=0,253 ; \mathrm{p}=$ $0,003)$; tussen Organisasieverbondenheid en Loopbaanverbondenheid $(r=0,411 ; p=0,000)$.

\section{BESPREKING}

Tydens hierdie studie is gebruik gemaak van 'n gerieflikheidsteekproef en nie 'n ewekansige steekproef nie. Om hierdie rede sal dit nie moontlik wees om die resultate tot die groter instelling of ander soortgelyke instellings te veralgemeen nie, maar het dit slegs betrekking op die mensbestuursdivisie van die betrokke instelling.

Die itemtellings van die werknemertevredenheid- en organisasieverwante verbondenheidmaatstawwe is gefaktoranaliseer (op twee vlakke) met 'n prosedure soos voorgestel deur Schepers (1992), ten einde die faktorstruktuur van die instrumente te bepaal. Die werknemertevredenheidvraelys (Weiss et al., 1967) het ' $n$ enkele skaal met ' $n$ bevredigende interne betroubaarheid van 0,91 opgelewer. Kaplan (1990) se rapportering van 'n betroubaarheidskoëffisiënt van 0,90 van die som van die 20 items ondersteun hierdie bevinding, so ook Welman en Basson (1995) se rapportering van 'n alfakoëffisiënt van 0,92. ('n Rekord van goeie betroubaarhede word dus opgebou). Die organisasieverbondenheidvraelys (Roodt, 1997) het twee skale opgelewer waar die eerste skaal die organisasieverbondenheidkonstruk verteenwoordig en die tweede skaal betrekking het op die loopaanverbondenheidkonstruk. Interne betroubaarhede van 0,95 en 0,85 is onderskeidelik opgelewer. Roodt (1997) se rapportering van 'n betroubaarheidskoëffisiënt van 0,91 ondersteun hierdie bevinding, so-ook Storm (2002) se rapportering van 'n alfakoëffisiënt van 0,94. ('n Bevestiging van goeie betroubaarhede word dus voortgesit).

Die primêre doel van die studie was om vas te stel of daar 'n verband tussen die werknemertevredenheid en die organisasieverbondenheid van werknemers binne die mensbestuurdivisie van 'n finansiële instelling bestaan. Ten spyte van transformasie en verandering wat veral op tegnologiese gebied plaasgevind het, dui beskrywende statistiek op 'n tevrede, homogene groep werknemers binne die Mensbestuurdivisie, omdat gemiddelde itemtellings hoër is as die skaalmiddelpunt. Hierdie resultate is vreemd, aangesien daar eerder verwag kon word dat genoemde veranderinge werknemers se werktevredenheid en ook hulle organisasieverbondenheid wesentlik sou raak. 'n Hoë mate van tevredenheid kom egter voor en kan die aanname gemaak word dat werknemers juis vanweë hulle loopbaanverbondenheid besonder toegewyd aan die organisasie is en daarmee saam verandering goed hanteer. Ten spyte van die transformasie is hulle nie vervreem nie en het hulle hul vertroue in die organisasie behou.

Daar is 'n hoë positiewe korrelasie tussen werknemertevredenheid- en organisasieverbondenheidtellings gevind. Die gevolgtrekking kan dus gemaak word dat hoe meer tevrede mense is, hoe groter sal hul gevoel van verbondenheid tot die organsisasie wees. Hoole (1997) kon dus met reg die opinie huldig dat organisasies opnuut moet fokus op hul menslikehulpbronne as hul belangrikste bate en op soek moet wees na maniere om werknemers se verbondenheidsvlakke te verhoog. Die resultate van hierdie studie bevestig Kanungo (1982) se bevindinge. Sy motiveringsbenadering beskou die konsepte van betrokkenheid en vervreemding as keersye van dieselfde muntstuk en stel 'n gëintegreerde raamwerk vir toekomstige sielkundige en sosiologiese navorsing voor.

Die resultate van hierdie studie bevestig ook Naumann (1993) se opinie dat sterk interaktiewe effekte tussen tevredenheid en verbondenheid voorkom en dat tevredenheid 'n voorspeller van verbondenheid kan wees. Dit bevestig verder ook die bevindinge van studies wat Kanungo rapporteer.

Kulturele en/of etiese verbintenis/vereenselwiging met die organisasie kan ook tot ' $n$ groter mate van verbondenheid met die organisasie lei en word ondersteun deur Sempane et. al (2002) se mening dat oganisatoriese klimaat en -kultuur bevorder kan word deur die behaling van werknemertevredenheid en organisatoriese doelwitte.

Loopbaanverbondenheid kom na vore as ' $\mathrm{n}$ afsonderlike faktor waarmee rekening gehou moet word. Alhoewel 'n lae korrelasie tussen werknemertevredenheid en loopbaanverbondenheid voorkom, kan die skep van "groei" geleenthede (byvoorbeeld skep van geleenthede binne die organisasie wat die verwesenliking van volle potensiaal binne 'n professionele loopaan moontlik maak) bydra tot 'n groter mate van loopbaanverbondenheid wat 'n hoër verband met werknemertevredenheid tot gevolg behoort te hê.

'n Sekondêre oogmerk was om te bepaal of enige biografiese veranderlikes hierdie verband tussen werknemertevredenheid en organisasieverbondenheid medieer. Geen betekenisvolle verskille in werknemertevredenheid-, organisasieverbondenheid- en loopbaanverbondenheidtellings in terme van biografiese kategorieë kon gevind word nie. Op grond hiervan is daar tot die gevolgtrekking gekom dat geen biografiese veranderlikes die verband tussen werknemertevredenheid, organisasieverbondenheid en loopbaanverbondenheid medieer nie. Hierdie resultate is vreemd, aangesien teoreties verwag kan word die biografiese veranderlikes wel 'n effek op veral werknemertevredenheid en organisasieverbondenheid sou hê.

Die resultate kan veralgemeen word na die onderhawige Mensbestuurdivisie. Dit genereer waardevolle inligting wat nuttig toegepas kan word, wat veral die bestuur van werknemers betref, met spesifieke verwysing na loopbaanverbondenheid. Groter fokus behoort geplaas te word op die opvolgbeplanningsproses en meer aandag behoort aan loopbaanaspirasies gewy te word. Die hoeveelheid geleenthede wat binne die organisasie bestaan wat verwesenliking van volle potensiaal binne 'n professionele loopbaan moontlik maak, behoort onder die vergrootglas geplaas te word.

Bestuur kan, deur middel van leierskap, 'n omgewing skep wat kenmerkend van 'n hoë mate van werksprestasie is - waarbinne werknemers kan en wil presteer. Werknemers behoort tot ' $n$ groter mate bemagtig te word om eienaarskap en verantwoordelikheid te neem, wat vergemaklik word deur toenemende demokratiese werkspraktyke (Van Dyk \& Herholdt, 2004). 
Die waarde van die studie kan ook gesien word in die identifisering van loopbaanverbondenheid as 'n afsonderlike faktor wat ' $n$ impak het op werknemertevredenheid en wat moontlikhede vir verdere navorsing inhou.

Toekomstige navorsing behoort egter na meerdere finansiële instellings uitgebrei te word. Terreine wat vir verdere navorsing ontgin kan word, is die volgende:

- Die modererende of medierende effek van biografiese veranderlikes;

- Die verband tussen sielkundige welstand van werknemers en hulle werksbetrokkenheid; en

- Die verband tussen fasette van intrinsieke en ekstrinsieke tevredenheid met organisasieverbondenheid.

\section{VERWYSINGS}

Agho, A., Mueller, C. \& Price, J. (1993). Determinants of employee job satisfaction: An empirical test of a causal model. Human Relations, 46, 1007-1027.

Akhtar, S. \& Chan, C.M. (1997). Three-dimensional Attitude Model of Organisational Commitment: Empirical validation using semantic measures. Paper presented at Fourth Annual International Conference on Advances in Management, Ontario, Canada, 9-12 July.

Allen, N.J. \& Meyer, J.P. (1990). The measurement and antecedents of affective, continuance and normative commitment to the organisation. Journal of Occupational Psychology, 63, 1-18.

Beehr, T.A. \& Gupta, N. (1978). A note on the structure of employee withdrawal. Organisational Behaviour and Human Performance, 21, 73-79.

Bergh, Z.C. \& Theron, A.L. (2003). Psychology in the work context. Oxford University Press.

Brown, R.B. (1996). Organisational Commitment: Clarifying the concept and simplifying the existing construct typology. Journal of Vocational Behaviour, 49, 230-251.

Carlopio, J. \& Gardner, D. (1995). Perceptions of work and workplace. Mediators of the relationship between job level and employee reactions. Journal of Occupational and Organisational Psychology, 68, 312-326.

Coster, E.A. (1992). The perceived quality of working life and job facet satisfaction. Journal of Industrial Psychology, 18 (2), 6-9.

Cranny, C., Smith, P. \& Stone, E. (1992). Job satisfaction: Advances in research and application. Lexington, MA: Lexington Books.

Davis-Blake, A. \& Pfeffer, J. (1989). Just a mirage: The search for dispositional effects in organisational research. Academy of Management Review, 14, 385-400.

Gurin, G., Veroff, J. \& Feld, S. (1960). Americans view their mental health. New York: Basic Books.

Hoole, C. (1997). Work commitment: It's dimensions and relationships with role stress and intention to quit. D. Phil proefskrif. Pretoria: UP.

Hrebiniak, L.G. \& Alutto, J.A. (1972). Personal and role-related factors in the development of organisational commitment. Administrative Science Quarterly, 18, 555-573.
Kaiser, H.F. (1970). A second-generation Little Jiffy. Psychometrika, 35, 401-415.

Kanungo, R.N. (1982). Measurement of job and work involvement. Journal of Applied Psychology, 67, 341-349.

Kreitner, R. \& Kinicki, A. (1998). Organizational Behaviour. Fourth edition, $207-208$.

Locke, E.A. (1976). The nature and causes of job satisfaction. In M.D. Dunette (ed.), Handbook of Industrial and organisational Psychology. Chicago: Rand - MC Nally

Mathieu, J.E. \& Zajac, D.M. (1990). A review and meta-analysis of the antecedents, correlates, and consequences of organizational commitment. Psychological Bulletin, 108 (2), 171 - 194.

Morrow, P.C. (1983). Concept redundancy in organisational research: The case of work commitment. Academy of Management Review, 8, 486-500.

Mowday, R.T., Steers, R.M. \& Porter, L.W. (1979). The measurement of organisational commitment. Journal of Vocational Behaviour, 14, 224-247.

Naughton, T.J. (1987). A conceptual view of workaholism and implications for career counselling and research. The Career Development Quarterly, 180 - 187.

Naumann, E. (1993). Antecedents and consequences of satisfaction and commitment among expatriate managers. Group \& Organisation Management, 18 (2), 153 - 188.

Reichers, A.E. (1985). A review and conceptualisation of organisational commitment. Academy of Management Review, 10, 465-476.

Roodt, G. (1991). Die graad van werkbetrokkenheid as voorspeller van persoonlike welsyn: 'n Studie by bestuurders. D Adminproefskrif. Bloemfontein: UOVS.

Roodt, G. (1997). Theoretical and empirical linkages between work-related commitment foci. Journal of Industrial Psychology, 23 (2) 6-13.

Sempane, M.E., Rieger, H.S. \& Roodt, G. (2002). Job satisfaction in relation to organisational culture. Journal of Industrial Psychology, 28 (2), 23-30.

Stewart, J.D. (1986). The power of people skills. New York: John Wiley \& Sons, Inc.

Stoner, J.A. \& Freeman, R.E. (1992). Management (5th ed.). New Jersey: Prentice Hall.

Storm, L. \& Roodt, G. (2002). Die verband tussen organisasiesosialisering en organisasieverbondenheid. Tydskrif vir Bedryfsielkunde, 28 (1), 14-21.

Testa, M.R. (2001). Organisational Commitment, Job Satisfaction, and Effort in the Service Environment. Journal of Psychology, 135 (2), 226 - 237.

Van Dyk, L. \& Herholdt, J. (2004). Transforming your Employment Brand. The Absa Experience. 17, 95, 111.

Visser, P.J. \& Breed, M. (1997). Employee-satisfaction: A triangulation approach. Journal of Industrial Psychology, 23 (2), 19-24.

Vroom, V.H. (1964). Work and motivation. New York: John Wiley and Sons.

Yousef, D.A. (1998). Satisfaction with job security as a predictor of organisational commitment and job performance in a multicultural environment. International Journal of Manpower, 19 (3), 184 - 195.

Zeitz, G. (1990). Age and work satisfaction is a government agency: A situational perspective, Human Relations, 43, 419-438. 